\title{
Absorption of primary macronutrients and soybean growth at different compactation densities and moisture levels in a silt loam soil ${ }^{1}$
}

\author{
Romano Roberto Valicheski ${ }^{*}$, Suzi Mari Brandelero ${ }^{3}$, David José Miquelutti ${ }^{4}$, Sidnei Leandro K.Stürmer ${ }^{5}$, \\ Antonio Luis Tramonti ${ }^{6}$, Marcos Cesar Franzão ${ }^{7}$
}

$10.1590 / 0034-737 X 201663020014$

\begin{abstract}
Soybean cultivation is increasing rapidly in the region of Alto Vale do Itajaí, State of Santa Catarina, where there is a predominance of silt soils. The objective of this work was to evaluate the content of primary macronutrients in shoots and shoot and root vegetative growth of soybean (Glicine max L. Merrill) grown in a silt-loam soil under different compactation densities and moisture levels. A randomized block design in a $4 \mathrm{x} 4$ factorial arrangement was used, with four compactation densities: $1.00 ; 1.20 ; 1.40$ and $1.60 \mathrm{Mg} \mathrm{m}^{-3}$, and four soil moisture levels: $0.130 ; 0.160 ; 0.190$ and 0.220 $\mathrm{kg} \mathrm{kg}^{-1}$ and four replications. Each pot consisted of the overlapping of three 150-mm PVC rings, where soil was maintained in the higher and lower part of the pot with a density of $1.00 \mathrm{Mg} \mathrm{m}^{-3}$ and in the intermediate ring, the compactation densities were increased. Values of soil density higher than $120 \mathrm{Mg} \mathrm{m}^{-3}$ negatively affected $\mathrm{N}, \mathrm{P}$ and $\mathrm{K}$ uptake by soybean plants, as well as the plant mass of the shoots and roots. The higher levels of soil moisture reduced the compaction effect and promoted better absorption of $\mathrm{P}$ and $\mathrm{K}$.
\end{abstract}

Key words: compactation density, nutrients uptake, root density, shoot system.

\section{RESUMO}

\section{Absorção de macronutrientes primários e desenvolvimento da soja em solo franco-siltoso sob diferentes níveis de compactação e umidade}

O cultivo da soja está em franca expansão na região do Alto Vale do Itajaí-SC, onde há predomínio de solos siltosos. Este trabalho teve por objetivo avaliar o teor de macronutrientes primários na parte aérea e o desenvolvimento vegetativo da soja (Glicine max L. Merrill), cultivada em solo franco-siltoso, sob diferentes níveis de compactação e umidade. Utilizou-se o delineamento em blocos casualizados, no esquema fatorial 4x4, sendo quatro níveis de compactação (densidades do solo de 1,00; 1,20; 1,40 e 1,60 $\left.\mathrm{Mg} \mathrm{m}^{-3}\right)$ e quatro níveis de umidade do solo (0,130; 0,160; 0190 e 0,220 kg kg-1), com quatro repetições. Cada vaso foi composto pela sobreposição de três anéis de PVC com diâmetro de $150 \mathrm{~mm}$, sendo no inferior e superior, mantido o solo com densidade de $1,00 \mathrm{Mg} \mathrm{m}^{-3}$, e no intermediário, implementados os níveis de compactação. Valores de densidade do solo superiores a 1,20 $\mathrm{Mg} \mathrm{m}^{-3}$ afetam de forma negativa a absorção de $\mathrm{N}$, de $\mathrm{Pe}$ de K, e a produção de biomassa de parte aérea e sistema radicular da soja. Níveis mais elevados de umidade do solo reduzem o efeito da compactação e favorecem a absorção de $\mathrm{P}$ e a de K.

Palavras-chave: densidade do solo; densidade de raízes; parte aérea; absorção de nutrientes.

\footnotetext{
Submitted on May 29, 2014 and accepted on October 26, 2015.

${ }^{1}$ Undergraduate project financed by Instituto Federal Catarinense

${ }^{* 2}$ Instituto Federal Catarinense, Rio do Sul, Santa Catarina, Brazil. valicheskiufrrj@yahoo.com.br

${ }_{3}^{3}$ Universidade do Estado de Santa Catarina, Centro de Ciências Agroveterinárias, Lages, Santa Catarina, Brazil. suzibrandelero@yahoo.com.br

${ }^{4}$ Universidade do Estado de Santa Catarina, Centro de Ciências Agroveterinárias, Lages, Santa Catarina, Brazil. a2djm@ cav.udesc.br

${ }_{5}^{5}$ Instituto Federal Catarinense, Rio do Sul, Santa Catarina, Brazil. sidineileandro@ gmail.com

${ }^{6}$ Instituto Federal Catarinense Rio do Sul, Santa Catarina, Brasil. biosolos@gmail.com

${ }^{7}$ Instituto Federal Catarinense Rio do Sul, Santa Catarina, Brasil. franzao@ifc-riodosul.edu.br

* Corresponding author: valicheskiufrrj@yahoo.com.br
} 


\section{INTRODUCTION}

In Brazil, soybean is one of the principal oilseed plants grown under no-tillage system (NTS). In this form of farming, during spraying and harvesting, a period when intense rainfall is often observed, there is a significant traffic of machines, while the soil is with high humidity, leading to soil compaction and, consequently, reduction of crop yield (Beutler et al., 2006). When compared to the conventional tillage system, soil management under the no-tillage system induces morphostructural modifications of the soil profile (Bronick \& Lal, 2005), reducing macroporosity and enhancing mechanical resistance to penetration, as well as soil density, thus changing the volume explored by the roots.

The compacted layer density able to restrict the growth of the plants varies according to the type of soil (Weirich Neto et al., 2002), moisture conditions (Silveira et al., 2010), species (Jimenez et al., 2008 ; Bonelli et al., 2011), or even the soybean cultivar (Foloni et al., 2003) since it significantly alters root growth (Cardoso et al., 2006; Freddi et al., 2009 ), water availability, and aeration (Hamza \& Anderson, 2005; Taiz \& Zaiger, 2008), the diffusive flow (Silva et al., 2008; Costa et al., 2009) and nutrient uptake by plants (Ahmad et al., 2009). However, excessively porous soils are also detrimental to the absorption of water and nutrients by the roots since there is less contact between soil and roots, resulting in lower development of plants (Hakansson et al., 1998)

According to Souza et al. (2012), for soybeans grown in a dystrophic red Latosol under different compactation levels (densities of $1.00 ; 1.20 ; 1.40$ and $1.60 \mathrm{Mg} \mathrm{m}^{-3}$ ), the increase in soil density caused a linear reduction in the contents of nitrogen, phosphorus and potassium in the shoots. According to the authors, the increase in soil density from $1.00 \mathrm{Mg} \mathrm{m}^{-3}$ to $1.60 \mathrm{Mg} \mathrm{m}^{-3}$ resulted in the reduction of 26,82 and $61 \%$ of the total of these elements accumulated by the plants, respectively.

With regard to the development of the aerial part of cotton, corn and soybeans, Silva et al. (2006) found in a Dark Red Latosol (Oxisol) under different levels of compactation (densities of 1.00; 1.20; 1.40 and $1.50 \mathrm{Mg} \mathrm{m}^{-}$ ${ }^{3}$ ) that it caused significant reductions in densities higher than $1.40 \mathrm{Mg} \mathrm{m}^{-3}$. According to these authors, for soybeans, at the density of $1.20 \mathrm{Mg} \mathrm{m}^{-3}$, plants showed higher height and greater dry matter production of shoots and fruiting parts.

Although there are many studies on the effect of compactation on plant growth, few studies have been developed in soils with high silt content, like those predominant in Alto Vale do Itajaí, State of Santa Catarina, a region where the no-tillage system is expanding, and soybean is one of main crops of commercial target.
In this context, the objective of this study was to evaluate the content of primary macronutrients in shoots as well as shoot and root vegetative growth of soybeans cultivated in a sandy-silty soil, under different levels of compactation and moisture.

\section{MATERIAL AND METHODS}

An experiment was carried out in a greenhouse at the Federal Institute of Santa Catarina - Rio Sul Campus, region of Alto Vale do Itajaí, State of Santa Catarina Brazil. The climate in the region is humid mesothermal with hot summer $(\mathrm{CFa})$, according to Köppen. Sixteen treatments were evaluated, set in a 4 x 4 factorial design, with four levels of soil compaction (densities of 1.00, $1.20,1.40$ and $1.60 \mathrm{Mg} \mathrm{m}^{-3}$ ) and four soil moisture levels $\left(0.130,0.160,0.190\right.$ and $\left.0.220 \mathrm{~kg} \mathrm{~kg}^{-1}\right)$. The random block design was used in the experiment with four replications. Each experimental unit was made up by overlapping three PVC rings with diameter of $150 \mathrm{~mm}$, where the higher and the lower ring had $0.10 \mathrm{~m}$ in height and the intermediate, in which the density levels were tested, had $0.05 \mathrm{~m}$. Because of being predominant in the region, the material used to fill the pots was collected at a depth of 0.0-0.20 m from a Cambisol with high silt content, located in a cropped area of the Federal Institute - Rio do Sul Campus. After collection, all material was crushed, air dried and sieved in 2.0-mm mesh sieve. Then, a composite sample was collected for chemical analysis (EMBRAPA, 1997), which showed water $\mathrm{pH}$ of 6.5, contents of calcium $\left(\mathrm{Ca}^{2+}\right)$, magnesium $\left(\mathrm{Mg}^{2+}\right)$, and aluminum $\left(\mathrm{Al}^{+3}\right)$, of $12.6 ; 4.5$ and $0.0 \mathrm{cmolc} \mathrm{dm}^{-3}$, respectively, and contents of phosphorus $(\mathrm{P})$ and potassium (K) of 51 and $341 \mathrm{mg} \mathrm{dm}^{-3}$ and base saturation of $77 \%$. In relation to the particle size, determined by the pipette method, it was obtained $240 \mathrm{~g}^{-1} \mathrm{~kg}$ of sand, $520 \mathrm{~g} \mathrm{~kg}^{-1}$ of silt and $240 \mathrm{~g} \mathrm{~kg}^{-1}$ of clay, and this soil was classified as sandy-silty. This sample was also used to pre-assemble volumetric rings with the tested soil density levels, where macroporosity and microporosity and total porosity were determined (Table 1).

In relation to levels of compactation, in the upper and lower layers of the pots (with $0.10 \mathrm{~m}$ of height in each side), soil was kept at the density of $1.00 \mathrm{Mg} \mathrm{m}^{-3}$ whereas in the intermediate layer ( $0.05 \mathrm{~m}$ of height), different levels of the established densities were used, aiming at covering density values from a recently cropped soil (not-restrictive) to those imposing severe limitation to plant growth, observed in some crops with compactation issues.

For pot assembling, the mass of soil dried in the air, used to fill each ring, was calculated from the mass of soil dried in a greenhouse, from which the existing moisture was discounted. 
To facilitate its accommodation in the rings, soil moisture was raised to $0.220 \mathrm{~kg} \mathrm{~kg}^{-1}$, where more susceptibility to compaction was observed. To obtain a more uniform compactation, the mass of the soil used for each ring was divided into three equal parts, each of them being compacted up to $1 / 3$ of the ring volume, and to prevent mirroring between the layers, a light scarification of the soil was carried out. To perform compaction, an iron socket with mass of $7.0 \mathrm{~kg}$ was used by letting it fall from a fixed height of $0.70 \mathrm{~m}$ onto a wood disc leaning on the material to be compacted, so the same compaction energy would be applied on each stroke. During the process, to avoid deformation of the pots, an iron strap with screw on its side was used. Firstly, the intermediate ring was filled in, then, the lower and, the higher, was the last to be filled in. After that, rings were junctioned with adhesive tape, by bending an edge of about $1 \mathrm{~cm}$ folded insidewards to avoid roots to grow between the compacted soil and the walls of the pot, especially at the highest levels of density. After assembly, the pots were supported by rigid plastic plate. For the cultivation of soybeans, considering the values obtained in the chemical analysis, fertilizer and soil amendment were applied.

Soil moisture was controlled by weighing the pots daily, calculating by the difference (between the initial mass and the real mass) the amount of water to be added and quantified by a measuring cylinder. Half of the volume was applied on the surface of the pot and half on the plastic plate on which it was supported to provide more uniform moisture all over the pot even at the highest compaction level so plants had to overcome the obstacle of the compacted layer for water and nutrients.

In soybean sowing (Cultivar CD 236 RR), three seeds per pot were used and, after germination, pruning was carried out, leaving only the most vigorous plant in each pot. During the experimental period, weeds and pests were controlled manually. Considering_the high water requirement of plants at the levels of the lowest density, the experimental harvest was carried out on day 30 after sowing. Before collection, the following evaluations were made: plant height, stem diameter, number of branches and fully developed leaves (considered those with completely one leaf limb). Then each plant was cut close to the ground, and the fresh matter of shoot was determined in a precision scale. After that, it was then wrapped in paper bag and dried in a forced air circulation oven $\left(65-70{ }^{\circ} \mathrm{C}\right)$, until constant weight, resulting in the determination of the dry matter of the shoot. Then the shoot was ground in a Wiley type mill, equipped with knives and stainless steel sieves ( $2 \mathrm{~mm}$ mesh) and packed in plastic containers until analysis. The methods described by Tedesco et al. (1995) for sulfuric digestion were used as well as for determination of nitrogen, phosphorus and potassium of the plant tissue.

At collection, after removal of the shoot, soil mechanical resistance to penetration (RP) was determined in the pots, using a metal rod penetrometer (Penetrolog 1020 model), recording the RP values every $10 \mathrm{~mm}$ of width. Then, to separate the rings, a saw blade was used at their junction and with a water jet, the existing roots in each fraction the pot were separated, and stored separately by layer in paper bags, dried $\left(65-70^{\circ} \mathrm{C}\right)$ in an oven with forced air circulation until constant weight. Then, the dry mass of roots was determined. The root density for each layer of the pot was obtained by dividing the root dry mass by the volume of each ring, and the result was expressed in $\mathrm{mg} \mathrm{cm}^{-3}$.

For data tabulating, the SAS-Statistical Analysis System (SAS Institute, 1999) was used to perform the analysis of variance by applying $\mathrm{F}$ test at $5 \%$ of probability. Once this was considered significant, the most appropriate regression model for each case was selected.

\section{RESULTS AND DISCUSSION}

The isolated effect of the factor soil moisture on the biometric variables (Table 2) was more significant for number of leaves (NL), number of branches (NB), stem diameter (SD) and dry matter of the shoot (DMS) than for plant height $(\mathrm{PH})$, where a significant linear decrease was found for each level tested. Thus, the reduction in moisture primarily affects the number of leaves and branches, stem diameter and dry mass of the shoot. Moreover, where there is better water availability, it may not necessarily affect plant height. The greater sensitivity of these variables to water deficit may be associated to the fact that soybean plants under conditions of lower water availability, absorpted fewer nutrients, thereby limiting the emission

Table 1: Macroporosity, microporosity and total porosity of soil at densities $1.00,1.20,1.40$ and $1.60 \mathrm{Mg} \mathrm{m}^{-3}$, tested in the pot intermediate layer

\begin{tabular}{lccc}
\hline Soil density & Macroporosity & Microporosity & Total porosity \\
\cline { 1 - 3 } \cline { 3 - 4 } $\mathbf{M g ~ m}^{-3}$ & & $\mathbf{m}^{\mathbf{3}} \mathbf{~ m}^{-\mathbf{3}}$ & 0.530 \\
\hline 1.00 & 0.160 & 0.370 & 0.490 \\
1.20 & 0.101 & 0.389 & 0.459 \\
1.40 & 0.052 & 0.407 & 0.401 \\
1.60 & 0.00 & 0.401 & \\
\hline
\end{tabular}


of leaves and branches, the development of the stem and the production of biomass for the shoot. The isolated effect of the factor soil density for the variables number of leaves, number of branches, plant height, stem diameter and fresh mass of the shoot was expressed in a linear reduction as levels of soil compactation increased (Table 2). For all these variables, despite the negative effect of soil density on plant growth, no statistical differences were found in soil density up to $1.20 \mathrm{Mg} \mathrm{m}^{-3}$, indicating that a slight compression, due to the enhancement in the contact between soil and root and the increase in the capacity of the soil to retain water, can promote plant growth. However, for higher densities (1.40 and $1.60 \mathrm{Mg} \mathrm{m}^{-3}$ ), a significant reduction was found in all variables in the shoot. Nevertheless, Silva et al. (2006) found a significant reduction in the shoot growth of soybean plants grown in an Oxisol with density values higher than $1.40 \mathrm{Mg} \mathrm{m}^{-3}$. The lowest density value in this study, from which soybean growth is affected, may be related to the high content of silt in this soil that, because of the peculiarities of this particle size fraction does not allow the formation of stable and deformation resistant microaggregates, promotes packing of mineral particles and compactation. At the highest level of compactation, as few roots were able to break the intermediate layer, the growth of the root system of the upper layer of the pot resulted in greater root density in this layer (Table 2), which has limited the volume of the exploited soil and, consequently, resulted in lower growth of the aerial part. According to Lipiec \& Stepniewski (1995), the effect of compaction on the transport of nutrients to the root depends on the intensity of soil compaction and water and nutrient supply, which may have limited the growth of soybean plants in the highest levels of the evaluated compactation. Beutler \& Centurion (2004) reported similar results for soybeans, grown on mediumtexture Red Latosol under different levels of compactation, where, at the highest levels, no concentration of roots was found in the soil surface layer and with a consequent reduction in crop yield.

The effect of the interaction between soil density and moisture to the variable fresh mass of the shoot is shown in Figures 1A and 1C. Regarding the effect of soil moisture (Figure 1A), it is observed that in all tested compactation levels, the increase of water content resulted in a linear increase in the fresh matter production of the shoot. This linear behavior for all tested soil density levels is related to the fact that moisture levels lower than moisture of the soil field capacity are used and, in these conditions, according to Silveira et al. (2010) and Molina Jr. et al. (2013), the greater the water content, the less the soil resistance to root growth, which favored the development of the shoot (Figure 1A) and roots (Figure 1B). According to Lipiec et al. (2009), a higher water content in the soil results in thickening of the water film between water and soil particles, thereby facilitating its movement through the roots and the reduction in the soil mechanical resistance to penetration, as a consequence.

As for the effect of soil density, at the moisture levels of 0.220 and $0.190 \mathrm{~kg} \mathrm{~kg}^{-1}$, the quadratic model was the one that provided the best adjustment (Figure 1C), being highly significant $(\mathrm{P}<0.01)$ and with $\mathrm{R}^{2}$ higher than 0.97 . For these treatments, no significant differences among soil

Table 2: Isolate effect of moisture and soil density on the number of leaves (NL), number of branches (NB), plant height (PH), stem diameter (SD), dry mass of shoots (DMS), root density, in the higher (HRD) and lower (LRD) layers of the pot

\begin{tabular}{|c|c|c|c|c|c|c|}
\hline \multicolumn{6}{|c|}{ Soil moisture $\left(\mathrm{kg} \mathrm{kg}^{-1}\right)$} & \multirow{2}{*}{$\mathbf{R}^{2}$} \\
\hline Variable & 0.220 & 0.190 & 0.160 & 0.130 & Regression model & \\
\hline $\mathrm{NL}$ & 9.94 & 8.31 & 5.25 & 3.75 & $\mathrm{y}=72.083 \mathrm{x}-5.8021$ & 0.98 \\
\hline NB & 4.56 & 4.19 & 2.19 & 1.25 & $y=39.792 x-3.9167$ & 0.94 \\
\hline $\mathrm{PH}(\mathrm{cm})$ & 9.66 & 9.47 & 8.16 & 7.62 & $y=30.063 x+3.3312$ & 0.94 \\
\hline $\mathrm{SD}(\mathrm{mm})$ & 3.85 & 3.42 & 2.58 & 2.03 & $y=20.927 x-0.6911$ & 0.99 \\
\hline $\operatorname{HRD}\left(\mathrm{mg} \mathrm{cm}^{3}\right)$ & 0.34 & 0.30 & 0.25 & 0.22 & $y=1.3667 x+0.0383$ & 0.99 \\
\hline $\operatorname{LRD}\left(\mathrm{mg} \mathrm{cm}^{3}\right)$ & 0.26 & 0.27 & 0.17 & 0.16 & $y=1.3333 x+0.0183$ & 0.79 \\
\hline DMS (g) & 2.35 & 2.07 & 1.39 & 0.96 & $y=20.927 x+0.6911$ & 0,99 \\
\hline \multicolumn{6}{|c|}{ Soil density $\left(\mathrm{Mg} \mathrm{m}^{-3}\right)$} & \multirow{2}{*}{$\mathbf{R}^{2}$} \\
\hline Variable & 1.00 & 1.20 & 1.40 & 1.60 & Regression model & \\
\hline NL & 7.31 & 7.69 & 6.81 & 5.44 & $y=-3.25 x+11.038$ & 0.99 \\
\hline NB & 3.44 & 3.44 & 2.88 & 2.44 & $y=-1.7813 x+5.3625$ & 0.90 \\
\hline $\mathrm{PH}(\mathrm{cm})$ & 9.71 & 8.8 & 8.16 & 7.63 & $y=-3.4906 x+13.13$ & 0.99 \\
\hline $\mathrm{SD}(\mathrm{mm})$ & 3.24 & 3.18 & 2.85 & 2.62 & $y=-1.1078 x+4.4113$ & 0.95 \\
\hline $\operatorname{HRD}\left(\mathrm{mgcm}^{3}\right)$ & 0.24 & 0.25 & 0.22 & 0.39 & $y=0.21 x+0.002$ & 0.49 \\
\hline $\operatorname{LRD}\left(\mathrm{mg} \mathrm{cm}^{3}\right)$ & 0.27 & 0.32 & 0.24 & 0.03 & $y=-0.4 x+0.735$ & 0.65 \\
\hline DMS (g) & 1.87 & 1.90 & 1.59 & 1.42 & $y=-0.8229 x+2.7632$ & 0.86 \\
\hline
\end{tabular}


densities of $1.00,1.20$ and $1.40 \mathrm{Mg} \mathrm{m}^{-3}$ were found. However, the maximum plant mass yield was obtained with density close to $1.20 \mathrm{Mg} \mathrm{m}^{-3}$. In these water conditions, the increment in the production of plant mass up to soil density of $1.20 \mathrm{Mg} \mathrm{m}^{-3}$ is associated with better physical conditions of the soil, thus promoting soil contact with the roots and the water dynamic in the soil and water absorption of nutrients, particularly the primary macronutrients such as phosphorus and potassium, as observed by Cabral et al (2012), as well.

For higher values of density, besides the physical impediment to root growth, another factor that may have contributed to the lower production of plant mass was the poor soil aeration, resulting from low macroporosity of the compacted layer (Table 1), making the growth of the roots difficult and not allowing an adequate gas exchange in the soil (Bronick \& Lal, 2005).

In relation to the density of roots of the compacted layer, the effect of the interaction between soil density and moisture is shown in Figures 1B and 1D. As soil moisture increased, root density linearly increased at the densities of 1.00, 1.20 and $1.40 \mathrm{Mg} \mathrm{m}^{-3}$ (Figure 1B), indicating that a higher water content in the soil, provided it is less than its field capacity, can mitigate the effects of compaction and promote root growth. Nevertheless, for compactation
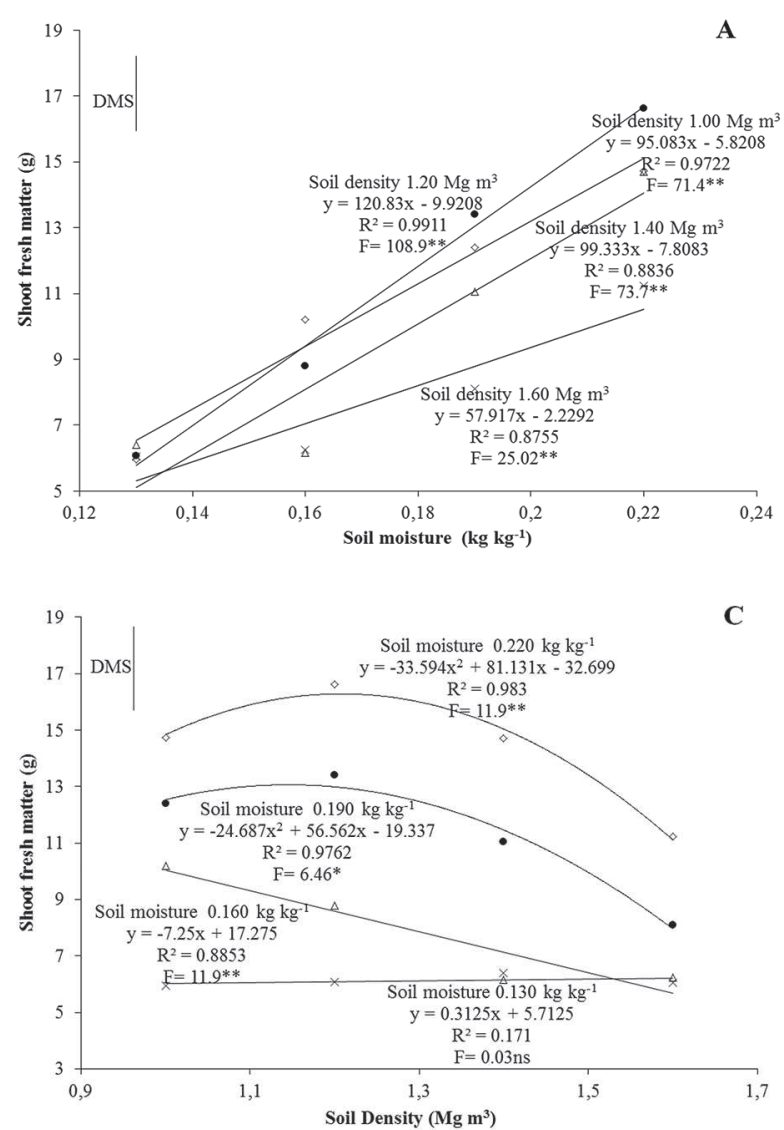

Figure 1: Shoot fresh matter and root density of soybean plant in the compacted layer for the different densities in function of soil moisture (A and B) and for the different moisture content in function of soil density (C and D).
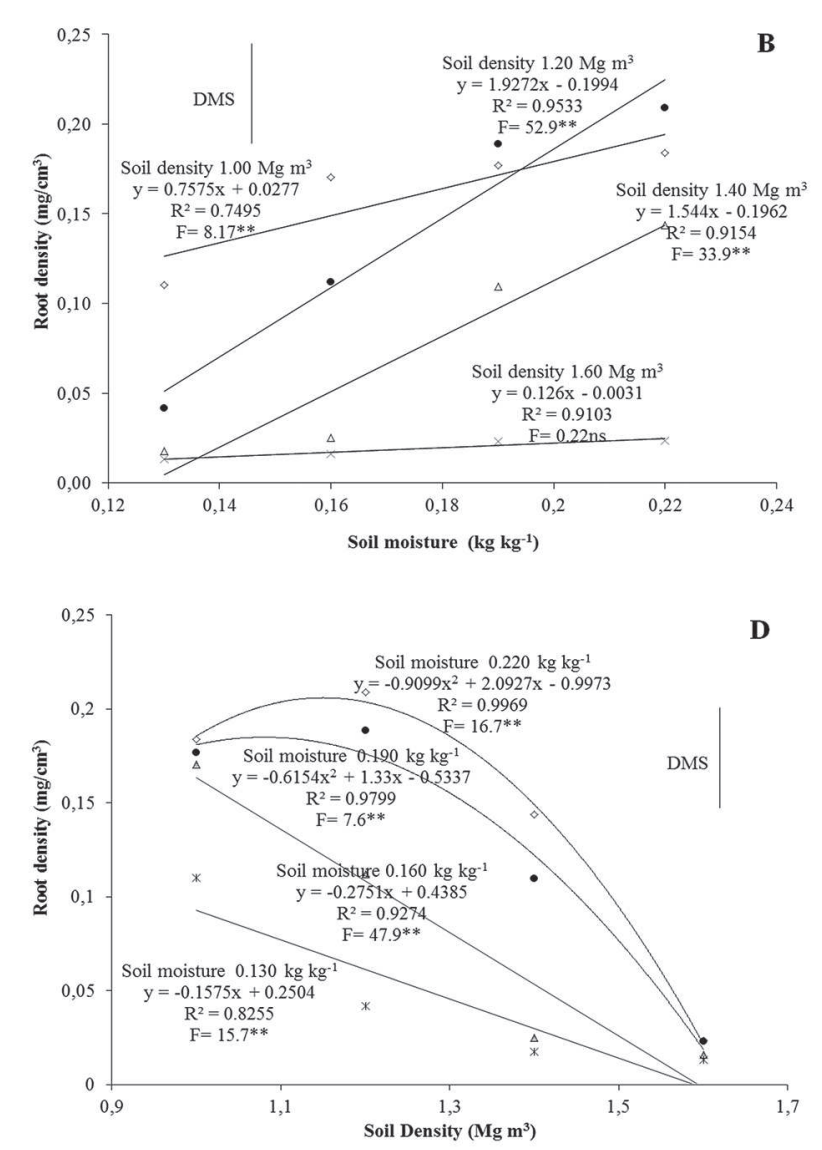

density of $1.60 \mathrm{Mg} \mathrm{m}^{-3}$, due to the severe physical restraint, no significant effects of the evaluated soil moisture levels were found.

Regarding the effect of the compactation levels for water conditions of 0.220 and $0.190 \mathrm{~kg} \mathrm{~kg}^{-1}$, a quadratic behavior was found, obtaining for those treatments a maximum root density ranging from 0.205 to $0.185 \mathrm{mg} \mathrm{cm}^{-3}$, with soil density ranging from 1.16 to $1.08 \mathrm{Mg} \mathrm{m}^{-3}$, respectively (Figure 1D). For these moisture levels in density values higher than $1.20 \mathrm{Mg} \mathrm{m}^{-3}$, a marked reduction in root density was found, indicating that values higher than this, can limit soybean plant growth, corroborating the results shown by Silva et al. (2006). However, for the conditions of lower water availability in the soil (0.160 and $\left.0.130 \mathrm{~kg} \mathrm{~kg}^{-1}\right)$, a linear decrease occurred as soil density increased. At these water conditions, according to the obtained models, an increase of $0.20 \mathrm{Mg} \mathrm{m}^{-3}$ of soil density results in a reduction of $34 \%$ in the root density of plants. For these moisture levels, root density obtained with a soil density of $1.00 \mathrm{Mg} \mathrm{m}^{-3}$ was statistically superior to that obtained with densities of 1.40 and $1.60 \mathrm{Mg} \mathrm{m}^{-3}$. This may be associated with macro and microporosity conditions that promote growth of soybeans root in depth to search for water, therefore mitigating its water shortage, since, during irrigations, water was also provided at the base of

Rev. Ceres, Viçosa, v. 63, n.2, p. 223-231, mar/abr, 2016 
the pots. However, it is clear that for compactation density, for values greater than $1.20 \mathrm{Mg} \mathrm{m}^{-3}$, root growth was significantly reduced, thus indicating they are limiting to the growth of soybeans.

When the data obtained for the fresh matter of shoots (Figure 1C) were compared with those obtained for root density (Figure 1D), it is observed that for all densities, the effect of soil compaction was more significant for root growth, confirming that this affects the development of root system first, and then, due to the decrease in the absorption of water and nutrients, the shoot development. However, in some cases, as evidenced by Valicheski et al. (2012), in situations of adequate and well distributed rainfall over the crop cycle, soybean yield may not be necessarily reduced.

It is shown in Figure 2, the effect of soil mechanical resistance to penetration in the compacted layer for root density (2A) and the shoot dry matter production (2B). At moisture levels of $0.220 \mathrm{~kg}$ and $0.190 \mathrm{~kg}^{-1}$, the quadratic model was the one that provided the best adjustment, where maximum values of 0.201 and $0.189 \mathrm{mg} \mathrm{cm}^{-3}$ were obtained for root density, and 2.57 and 2.34 g plant $^{-1}$ for dry matter of the shoot, with, respectively, 0.80 and $0.70 \mathrm{MPa}$ of soil mechanical resistance to penetration. The reduction in the soybean growth for PR values higher than $0.80 \mathrm{MPa}$ may have occurred due to several reasons, among which, it can be highlighted the morphological changes of the root system (twisted and necrotic roots), visually observed in the two highest levels of compactation density, resulting in lower plant mass of roots and the exploited soil volume, thereby reducing the use of water. Similar values of PR are also reported by Beutler \& Centurion (2004), who mention the reduction in soybean yield for soil mechanical resistance to penetration greater than $0.85 \mathrm{MPa}$. Since Beutler et al. (2006) reported the reduction in the yield from only 2.2 MPa, which was associated with the fact that the experiment was carried out in field conditions and in times of high rainfall, therefore, softening the effects of the evaluated effects of compactation.

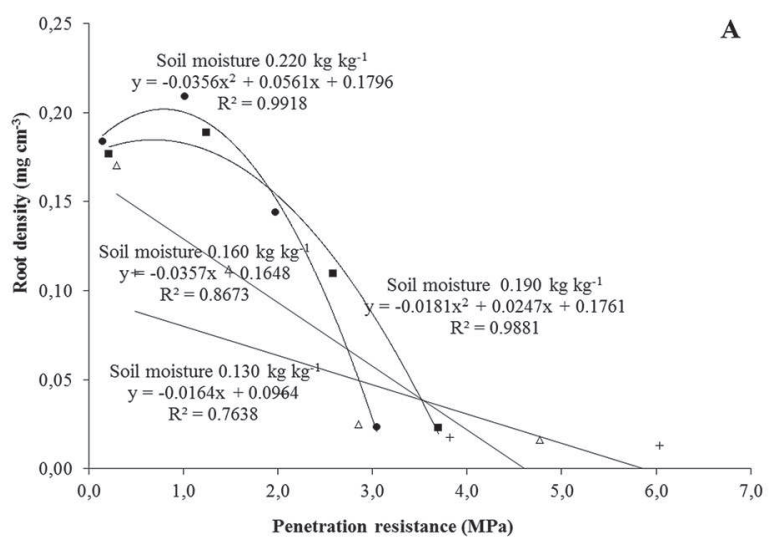

At the units 0.220 and $0.190 \mathrm{~kg} \mathrm{~kg}^{-1}$, although maximum values of root density of the compacted layer and dry matter of the shoot with PR values were close to $0.80 \mathrm{MPa}$ (Figure 2) compared with the calculated for $1.50 \mathrm{Mpa}$, a reduction of 8.9 and $6.5 \%$ of the root density occurred, and of 2.5 and $4.2 \%$ of the dry matter production of the shoot, respectively, indicating that if the soil is maintained in these water conditions, soybean has its vegetative growth little affected up to 1.5 MPa. However, for higher values, there is a marked reduction of both variables, more expressive for root density, however. This fact is more evident when the model obtained in soil moisture of 0.160 $\mathrm{kg} \mathrm{kg}^{-1}$ was analyzed, in which for root density as well as for production of shoot dry matter, a linear decrease with increasing resistance to penetration was found, which was more pronounced for root density. At moisture of $0.130 \mathrm{~kg}$ $\mathrm{kg}^{-1}$, although less dry matter of shoots was obtained due to severe water restriction, a reduction was found only in the root density when PR was increased.

The determination of the critical value of PR for the growth of soybean plants is as important as the root growth. Thus, according to the quadratic regression model between the PR and root density, for silty soils similar to the one used in this study maintained with moisture levels of 0.220 and $0.190 \mathrm{~kg} \mathrm{~kg}^{-1}$, the value of $0.80 \mathrm{MPa}$ can be set as critical, from which the reduction in the growth of soybean plants starts. This value is lower than $2 \mathrm{MPa}$, proposed as critical by Tormena et al. (1998) during the characterization of an optimal water range of an Oxisol under no-tillage, but higher than the value presented by Rosolem et al. (1994), who report for a darkred Latosol maintained with moisture content around $80 \%$ of its field capacity, a reduction of $50 \%$ of the root growth of soybean plants in PR of 0.69 Mpa.

In relation to the absorption of nitrogen $(\mathrm{N})$, phosphorus $(\mathrm{P})$ and potassium $(\mathrm{K})$, it can be seen in Figures $3 \mathrm{~A}, \mathrm{C}$ and $\mathrm{E}$, the effect of compactation on the content of these elements in the shoot tissues of soybeans. At the

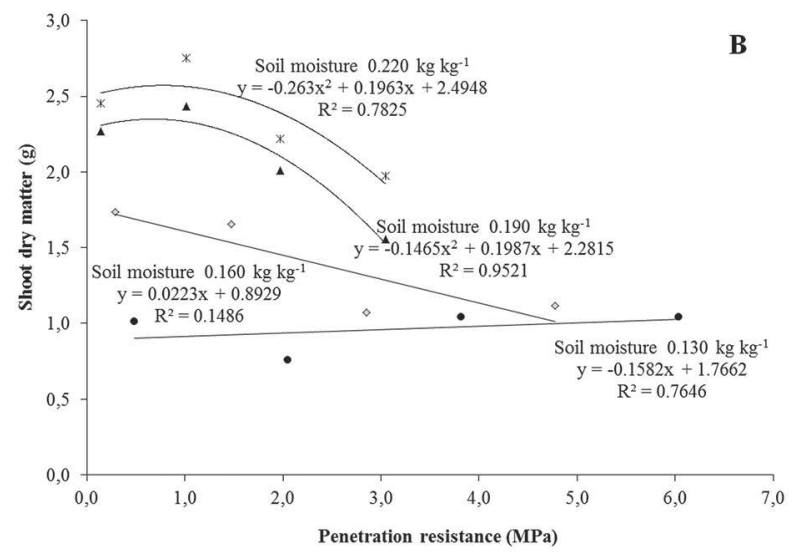

Figure 2: Root density of soybean plants on the basis of root dry matter (A) and on the production of shoot dry matter (B), in the different levels of moisture in function of mechanical resistance to penetration in the pot compacted layer. 
moisture levels of 0.220 and $0.190 \mathrm{~kg} \mathrm{~kg}^{-1}$ for the three evaluated elements, the quadratic regression model provided the best adjustment, with maximum absorption occurring in values of soil density close to $1.20 \mathrm{Mg} \mathrm{m}^{-3}$. As for the lowest moisture levels (0.160 and $\left.0.130 \mathrm{~kg} \mathrm{~kg}^{-1}\right)$, a linear decrease in $\mathrm{N}$ and $\mathrm{P}$ (Figures $3 \mathrm{~A}$ and $3 \mathrm{C}$ ) was found. For the two highest levels of moisture, as it has already been reported, soil densities with values close to $1.20 \mathrm{Mg}$ $\mathrm{m}^{-3}$, favored the root system growth, because of better physical and water conditions of the soil, increasing the volume of soil explored and, consequently, the uptake of
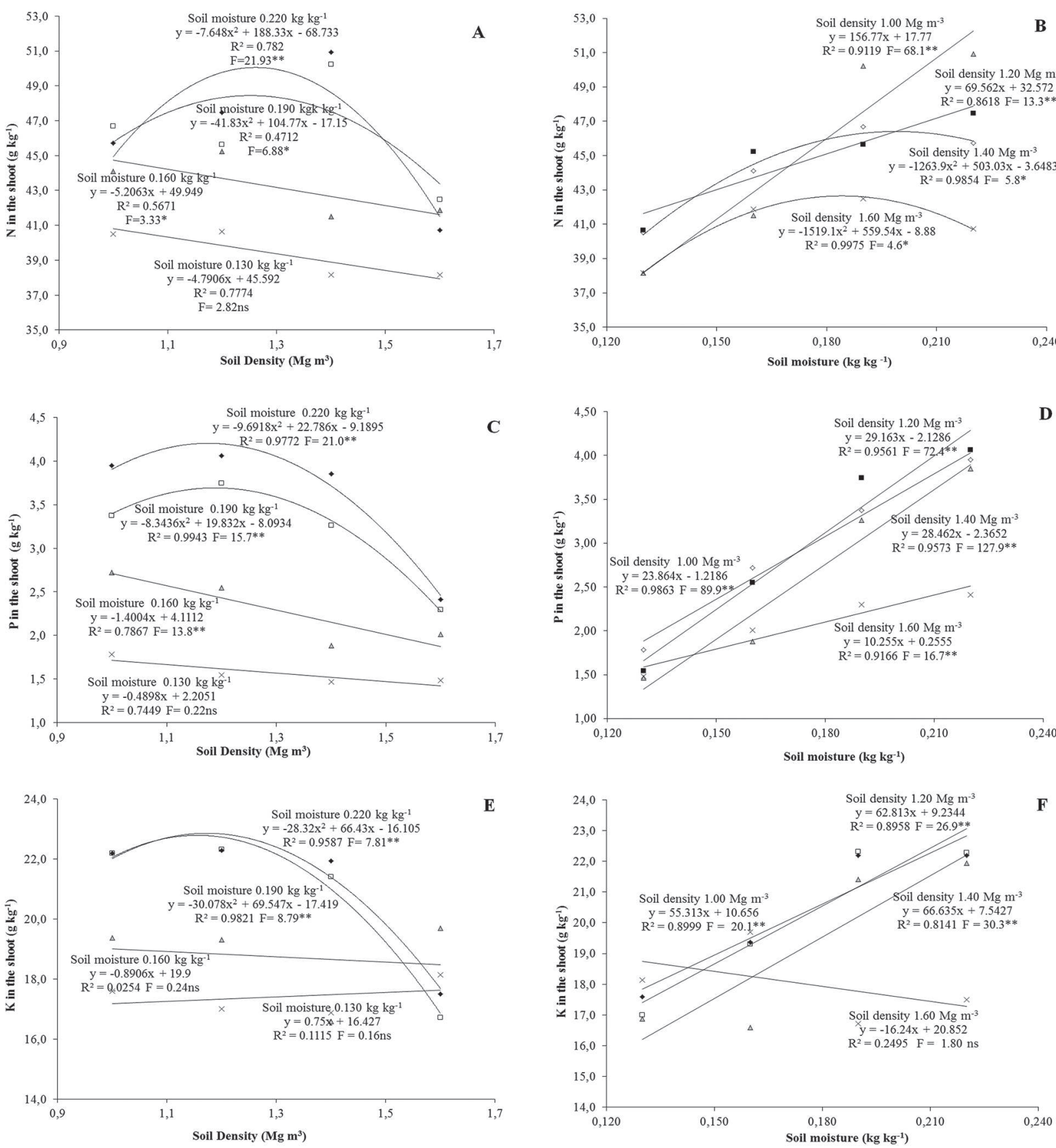

Figure 3: Content of nitrogen, phosphorous and potassium in the shoot of soybean plants at moisture levels in function of soil density ( $\mathrm{A}, \mathrm{C}$ and $\mathrm{E}$ ) and, at densities in function of soil moisture (B, D and F).

$\mathrm{N}, \mathrm{P}$ and $\mathrm{K}$. At this condition, adequate soil moisture and aeration are also factors that promote the mineralization of organic matter, providing greater amount of elements for plants. In addition, another fact that must be considered is the occurrence of less tortuosity and larger diameter of the micropores (when compared to the values of higher density), promoting the increase in diffusive flow of $\mathrm{P}$ and K, as reported by Silva et al. (2008) and Costa et al. (2009), as well as the lowest resistance to penetration of roots, resulting in greater absorption of these and other nutrients. For higher values of soil density, restriction to the growth

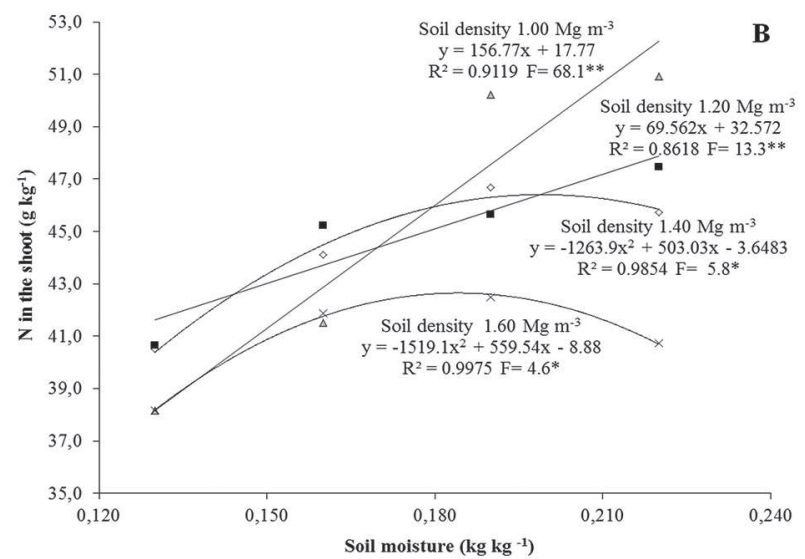


of plant roots, associated with lower mineralization of soil organic matter, resulted in less absorption of $\mathrm{N}, \mathrm{P}$ and $\mathrm{K}$, corroborating the results obtained by Souza et al. (2012), who found a reduction in the absorption of $\mathrm{N}, \mathrm{P}$ and $\mathrm{K}$ in soybeans, as density of the soil was increased. According to Novais \& Smyth (1999), compactation reduces soil aeration and mineralization of organic matter, increases the energy of water retention in the soil by increasing its viscosity, and the interaction of phosphate and potassium ions with the surface of colloids over its diffusion path, causing them to have to move closer and closer to positively charged surfaces, which hinders the absorption of these elements at the highest levels of compactation.

In relation to the effect of moisture in different soil densities, a quadratic behavior was found for nitrogen (Figure 3B) at the densities of 1.40 and $1.60 \mathrm{Mg} \mathrm{m}^{-3}$, obtaining maximum levels of $\mathrm{N}$ in the shoot at the moisture level of 0.180 and $0.200 \mathrm{~kg} \mathrm{~kg}^{-1}$, respectively. At these densities, the reduction of $\mathrm{N}$ content in the highest moisture levels may be associated with poor oxygenation of the soil as well as the restriction of the root growth. As for the densities of 1.00 and $1.20 \mathrm{Mg} \mathrm{m}^{-3}$, there was a linear increase in the content of $\mathrm{N}$ as soil moisture increased. This linear increase was also observed for the $\mathrm{P}$ content in all tested levels of density and for $\mathrm{K}$, at the densities of $1.00 ; 1.20$ and $1.40 \mathrm{Mg} \mathrm{m}^{-3}$. In addition to promoting the mineralization of soil organic matter, the greater availability of water in the soil also causes thickening of the water film around the mineral particles of the soil, avoiding the $\mathrm{P}$ and $\mathrm{K}$ to move closer to the soil colloids thereby reducing their attachment and therefore favoring their uptake by the plants. Moreover, in situations of greater water availability, as long as it is lower than the moisture of soil saturation, there is a higher photosynthetic rate in the leaves, with a consequent production of carbohydrates (Taiz \& Zeiger, 2008), resulting in greater absorption of nutrients by increasing the production of dry mass of roots and shoots of the plants.

\section{CONCLUSIONS}

For soils with high silt content in the region of Alto Vale do Itajaí, State of Santa Catarina, Brazil, soil compactation higher than $1.20 \mathrm{Mg} \mathrm{m}^{-3}$ becomes restrictive to soybean growth.

Even in favorable soil moisture conditions $(0.220$ and $\left.0.190 \mathrm{~kg} \mathrm{~kg}^{-1}\right)$, values of soil mechanical resistance to penetration higher than $0.80 \mathrm{MPa}$ reduce root growth and dry matter production of shoots of soybean plants.

The best conditions of water availability and soil densities up to $1.20 \mathrm{Mg} \mathrm{m}^{-3}$ promote plant growth and uptake of phosphorus and potassium.

\section{AKNOWLEDGEMETNS}

The authors thank the Federal Institute of Santa Catarina - Campus Rio do Sul for the opportunity to carry out this work; CNPq for financial support and the UDESCCAV Lages, for allowing the use of the Soils Laboratory

\section{REFERENCES}

Ahmad N, Hassan FU \& Belford RK (2009) Effect of soil compaction in the sub-humid cropping environment in Pakistan on uptake of NPK and grain yield in wheat (Triticum aestivum) I. Compaction. Field Crops Research, 110:54-60.

Beutler NA \& Centurion JF (2004) Compactação do solo no desenvolvimento radicular e na produtividade da soja. Pesquisa Agropecuária Brasileira, 39:581-588.

Beutler AN, Centurion AF, Centurion MAP \& Silva AP (2006) Efeito da compactação na produtividade de cultivares de soja em Latossolo Vermelho. Revista Brasileira de Ciência do Solo, 30:787-794.

Bonelli EA, Bonfim-Silva EM, Cabral CEA, Campos JJ, Scaramuzza LMP \& Polizel AC (2011) Compactação do solo: Efeitos nas características produtivas e morfológicas dos capins Piatã e Mombaça. Revista Brasileira de Engenharia Agrícola e Ambiental, 15:264-269

Bronick CJ \& Lal R (2005) Soil structure and management: Areview. Geoderma, 124:3-22.

Cabral CEA, Bonfim-Silva EM, Bonelli EA, Silva TJA, Cabral CHA \& Scaramuzza WLMP (2012) Compactação do solo e macronutrientes primários na Brachiaria brizantha cv. Piatã e Panicum maximum cv. Mombaça. Revista Brasileira de Engenharia Agrícola e Ambiental, 16:362-367.

Cardoso EG, Zotarelli L, Piccinin JL, Torres E, Saraiva OF \& Guimarães MF (2006) Sistema radicular da soja em função da compactação do solo no sistema plantio direto. Pesquisa Agropecuária Brasileira, 41:493-501.

Costa JPV, Barros NF, Bastos AL \& Albuquerque AW (2009) Fluxo difusivo de potássio em solos sob diferentes níveis de umidade e de compactação. Revista Brasileira de Engenharia Agrícola e Ambiental, 13:56-62.

EMBRAPA - Empresa Brasileira de Pesquisa Agropecuária (1997) Manual e métodos de análises de solo. $2^{\text {a }}$ ed. Rio de Janeiro, Embrapa Solos. 212p.

Freddi OS, Centurion JF \& Almeida CX (2009) Compactação de um Latossolo Vermelho de textura argilosa afetando o sistema radicular e a produtividade do milho. Revista Ceres, 56:654665 .

Foloni JSS, Calonego JC \& Lima SL (2003) Efeito da compactação do solo no desenvolvimento aéreo e radicular de cultivares de milho. Pesquisa Agropecuária Brasileira, 38:947-953.

Hakansson I, Stenberg M \& Rydberg T (1998) Long term experiments with different depths of mouldboard plough in Sweden. Soil and Tillage Research, 46:209-223.

Hamza MA \& Anderson WK (2005) Soil compaction in cropping systems: A review of the nature, causes and possible solutions. Soil \& Tillage Research, 82:121-145.

Jimenez RL, Gonçalves WG, Araújo Filho JV, Assis RL, Pires FR \& Silva GS (2008) Crescimento de plantas de cobertura sob diferentes níveis de compactação em um Latossolo Vermelho. Revista Brasileira de Engenharia Agrícola e Ambiental, 12:116121. 
Lipiec J \& Stepniewski W (1995) Effects of soil compaction and tillage systems on uptake and losses of nutrients. Soil and Tillage Research, 35:37-52.

Lipiec J, Wójciga AR \& Horn R (2009) Hydraulic properties of soil aggregates as influenced by compaction. Soil \& Tillage Research, 103:170-177.

Molina Júnior WF, Piedade SMS \& Amaral JR (2013) Penetration resistance in a Latosol under different moisture and penetration speeds. Revista Ceres, 60:715-721.

Novais RF \& Smyth TJ (1999) Fósforo em solo e planta em condições tropicais. Viçosa, Universidade Federal de Viçosa. $399 \mathrm{p}$.

Rosolem CA, Almeida ACS \& Sacramento LVS (1994) Sistema radicular e nutrição da soja em função da compactação do solo. Bragantia, 53:259-266.

SAS Institute Inc. (1999) Statistical Analysis System user's guide. Version 8.0. North Caroline, Statistical Analysis System Institute. $3365 \mathrm{p}$

Silva GJ, Maia JCS \& Bianchini A (2006) Crescimento da parte aérea de plantas cultivadas em vaso, submetidas à irrigação subsuperficial e a diferentes graus de compactação de um Latossolo Vermelho-Escuro distrófico. Revista Brasileira de Ciência do Solo, 30:31-40.

Silva SR, Barros NF \& Souza CM (2008) Fluxo difusivo de fósforo e zinco influenciado pela compactação de dois Latossolos. Revista Ceres, 55:619-624.
Silveira DC, Melo Filho JF, Sacramento JAAS \& Silveira ECP (2010) Relação umidade versus resistência à penetração para um Argissolo Amarelo distrocoeso no recôncavo da Bahia. Revista Brasileira de Ciência do Solo, 34:659-667.

Souza MAS, Faquin V, Guelfi DR, Oliveira GC \& Bastos CEA (2012) Acúmulo de macronutrientes na soja influenciado pelo cultivo prévio do capim-marandu, correção e compactação do solo. Revista Ciência Agronômica, 43:611-622.

Taiz L \& Zeiger E (2008) Fisiologia vegetal. $4^{\mathrm{a}}$ ed. Porto Alegre, Artmed. 819p.

Tedesco MJ, Gianello C, Bissani CA, Bohnen H \& Wolkweiss SJ (1995) Análises de solo, plantas e outros materiais. $2^{\mathrm{a}}$ ed. Porto Alegre, Universidade Federal do Rio Grande do Sul. 174p.

Tormena CA, Silva AP \& Libardi PL (1998) Caracterização do intervalo hídrico ótimo de um Latossolo Roxo sob plantio direto. Revista Brasileira de Ciência do Solo, 22:573-581.

Valicheski RR, Grossklaus F, Stürmer SLK, Tramontin AL \& Baade ESAS (2012) Desenvolvimento de plantas de cobertura e produtividade da soja conforme atributos físicos em solo compactado. Revista Brasileira de Engenharia Agrícola e Ambiental, 16:969977.

Weirich Neto PH, Rosa ALT \& Gomes JA (2002) Suscetibilidade de dois tipos de solo à compactação. Revista Brasileira de Engenharia Agrícola e Ambiental, 6:349-353. 